\title{
多孔質骨材を用いたコンクリートの空隙特性と力学的特性 CORRELATION OF POROSITY AND MECHANICAL PROPERTY
OF CONCRETE CONTAINING POROUS AGGREGATE
}

三浦隆広*1, 菊池雅史*2, 小山明男*3, 秋庭淳二*4 Takahiro MIURA, Masafumi KIKUCHI, Akio KOYAMA and Junji AKIBA

\begin{abstract}
In recent years, various kinds of aggregates are being developed for the purpose of resources recovery of solid waste. Generally, these types aggregates contain microscopic porosity in these matrixes.

These aggregates show many different properties comparing with conventional artiticial lightweight aggregate, such as chemical composition, manufacturing process, internal structure and external surface structure and external surface. textures. Variation of properties, density, absorption, strength, etc of porous aggregate are caused by reasons above-mentioned.

According to our series studies, it was observed that properties of porous aggregate, density, absorption, strength, etc can be evaluated by porosity as common index, and porosity has a high correlation with three properties.

Based on the past above investigation, this study was carried out in these experimental series.

Series I : Characteristic of porous aggregate

Series II : Correlation of porosity and mechanical properties of mortar and concrete containing porous aggregate.

Series III: Correlation of porosity and mechanical properties of mortar and concrete containing normal aggregate and porous aggregate. Volume and radius of porosity, density, absorption, strength of aggregate in series I, volume of porosity, density, compressive strength, Young's Modulus of mortar in series II, volume of porosity, density, compressive strength, Young's Modulus of concrete in series III were measured respectively.

Porosity of aggregate, mortar and concrete, density, compressive strength, and young's modulus are measured.
\end{abstract}

Keywords : porous aggregates, porosity, mortar, concrete, mechanical property

多孔質怚材，空隙特性，モルタル，コンクリート，力学的特性

1.はじめに

コンクリートに要求される代表的品質のひとつに縮強度がある。 王縮強度について法,その所要品質を確保する手法として，水セメ ント比による調合設計法が広く採用されている。また，資源の有効 利用を目的に各種産業廃棄物，工業副産物を主原料とした骬材が開 発，実用化され始めた現状にある。このような状況下において，こ 扎骨材を用いたコンクリートにあっては，水セメント比のみで所 紫品質を確保することの困難さが指摘されている。その主な理由と して，こ扎䯈材は空隙を多量に含んでおり，ペーストあるいはモ ルタルの強度に比べて骨材の強度・用性が小さいことがあげられる。

多孔材料の空隙特性と力学的特性に注高い相関性があることは広 く知られており，セメント系材料についても，鎌田 ${ }^{12}$ ，湯浅ら ${ }^{2)}$ じめとした研究者らによる多くの報告がみられる。

しかし，セメント硬化体中の空隙と骨材中の空隙の双方に着目し て圧縮強度との関係を解明した研究はほとんどみられない。

筆者らは，これまで，軽量骨材や超軽量骨材，あるいは再生骨材 等のように冒材中に普通骨材に比べて多量の空隙を有する县材（以 下，多孔質骨材という）を用いた各種コンクリートの性質について 公籁囲な実験的研究 ${ }^{3)}{ }^{4)}$ を継続してきている。これらの研究から，
多孔質骨材を用いたコンクリート（以下，多孔質骨材コンクリート という）の力学的特性は，コンクリートの調合条件，材踰，養生方 法等の因子により，大きく影響されること，その影響の程度が拍通 コンクリートに比べて大きいこと，また,これら影響因子は最終的に コンクリート中の空隙特性で置き換えられることの判断を得ている そこで本研究は，多孔質骨材を用いたコンクリートの材料設計の 基礎的資料を得るための前段として，コンクリートの力学的特性を コンクリート容積に占める全空隙容積により評価することの妥当性 の確認を主な目的として着手したものである。

\section{2. 本研究の進め方}

2.1 本研究における多孔筫骨材コンクリートのモデル

図 1 は，任意の容積を持つ多孔質骨材コンクリートの断面を示し たものである。この図において，コンクリートの容積 $\left({ }_{\mathrm{c}} \mathrm{V}\right)$ 注，(1) 式によって表される。

${ }_{\mathrm{c}} \mathrm{V}={ }_{\mathrm{p}} \mathrm{V}+{ }_{\mathrm{s}} \mathrm{V}+{ }_{\mathrm{G}} \mathrm{V}$

(1)式

ここに, ${ }_{\mathrm{p}} \mathrm{V}$ : 硬化したセメントペーストの容積 $\left(\mathrm{m}^{3}\right)$

$s \mathrm{~V}:$ 多孔質細骨材の容積 $\left(\mathrm{m}^{3}\right)$

${ }_{\mathrm{G}} \mathrm{V}$ : 多孔質粗骨材の容積 $\left(\mathrm{m}^{3}\right)$
*1 前田建設工業 工博

*2 明治大学理工学部建築学科 教授. 工博

*3 明治大学理工学部建築学科 講師 · 工博

*4 前田建設工業 工修
Maeda Corporation, Dr. Eng.

Prof., Dept. of Architecture, Science and Technology, Meiji Univ., Dr. Eng. Lecturer, Dept. of Architecture, Science and Technology, Meiji Univ., Dr. Eng. Maeda Corporation, M. Eng. 
${ }_{p} V,{ }_{s} V$ および ${ }_{\mathrm{G}} \mathrm{V}$ が, それぞれ空隙を含まない固体部の容積 $\left(\mathrm{p} \mathrm{V}_{\mathrm{s}}, \mathrm{s}_{\mathrm{s}}\right.$ および $\left.{ }_{\mathrm{G}} \mathrm{V}_{\mathrm{s}}\right)$ と空纱部の容積 $\left(\mathrm{P}_{\mathrm{P}}, \mathrm{V}_{\mathrm{S}} \mathrm{V}_{\mathrm{p}}\right.$ および $\left.\mathrm{G}_{\mathrm{p}}\right)$ よりなるとすれば, 备材料の容積は(2)式から(4)式で表される。

${ }_{\mathrm{p}} \mathrm{V}=\mathrm{p}_{\mathrm{p}} \mathrm{V}_{\mathrm{s}}+\mathrm{p}_{\mathrm{p}} \mathrm{V}_{\mathrm{p}}$

${ }_{9} V={ }^{s} V^{s}+{ }^{s} V^{p}$

(3)式

${ }_{\mathrm{G}} \mathrm{V}={ }_{\mathrm{G}} \mathrm{V}_{\mathrm{s}}+{ }_{\mathrm{G}} \mathrm{V}_{\mathrm{p}}$

(4)式

以上の(1)式〜(4)式より， $\mathrm{V} V$ は(5)式で表される。

$\mathrm{C}=\left({ }_{\mathrm{p}} \mathrm{V}_{\mathrm{s}}+{ }_{\mathrm{s}} \mathrm{V}_{\mathrm{s}}+{ }_{\mathrm{G}} \mathrm{V}_{\mathrm{s}}\right)+\left({ }_{\mathrm{p}} \mathrm{V}_{\mathrm{p}}+{ }_{\mathrm{s}} \mathrm{V}_{\mathrm{p}}+{ }_{\mathrm{G}} \mathrm{V}_{\mathrm{p}}\right)$

(5)式

本研究は, (5)式のコンクリート中の全空隙容積 $\left({ }_{\mathrm{p}} \mathrm{V}_{\mathrm{p}}+{ }_{\mathrm{s}} \mathrm{V}_{\mathrm{p}}+{ }_{\mathrm{G}} \mathrm{V}_{\mathrm{p}}\right)$ と力 学:的特性の相関性を実験により求めるものである。

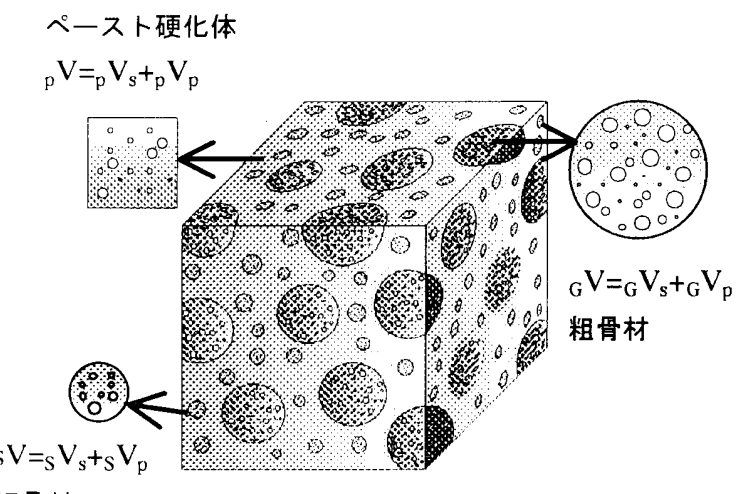

細骨材

図 1 多孔質骨材コンクリートのモデル

\section{2 実験の進め方}

コンクリート中の全空隙容積と力学的特性の間に高い相関性があ ること在検証するために，以下のような段階的な研究計画を進めた。 シリーズI：多孔質骨材の空隙特性に関する研究

シリーズ円：多孔質骨材を用いたモルタルおよびコンクリートの空 㩐特性上力学的特性に関する研究

シリーズIII：普通骨材と多孔質骨材を用いたモルタルおよびコンク リートの空隙特性と力学的特性に関する研究

\section{3 実験結果を整理するうえでの仮説}

本研究では，多孔質骨材モルタルおよびコンクリート中の全空隙 窘積と力学的特性の相関性を求めるにあたり, 以下に示す 3 つの仮 説在たてた。

【仮説 1】ベーストの硬化および乾燥による収縮応力は，いずれの材 齢においても，細骨材および粗骨材に均等に分配されるものとする。

【仮説 2】各種応力に伴うべースト, 細骨材および粗骨材の容積减少 ○比率法同じとする。

【仮説 3】【仮説 1】，【仮説 2】のもとで，コンクリートの空隙特性に 対する空渻の変動因子は，ベーストの空隙のみとする。

以上の【仮説 1】【仮説 2】は,硬化および乾喍収縮応力, ペースト 上惄材界面(普通骨材を除く)の付着状況，収縮ひび割れおよびそれに 伴う志力弛緩，等については考虑していないことを示すものである。 【仮説3】㳉，練混ぜ時の骨材の破壊，セメントベーストが骨材の空 偝部へ侵入することによる骨材の空览特性の変化は考虑しないこと 在亦すものである。

\section{3.実験概要}

3.1 シリーズ I：多孔質骨材の空陌特性に関する研究
表 1 骨材の主要物性の概要

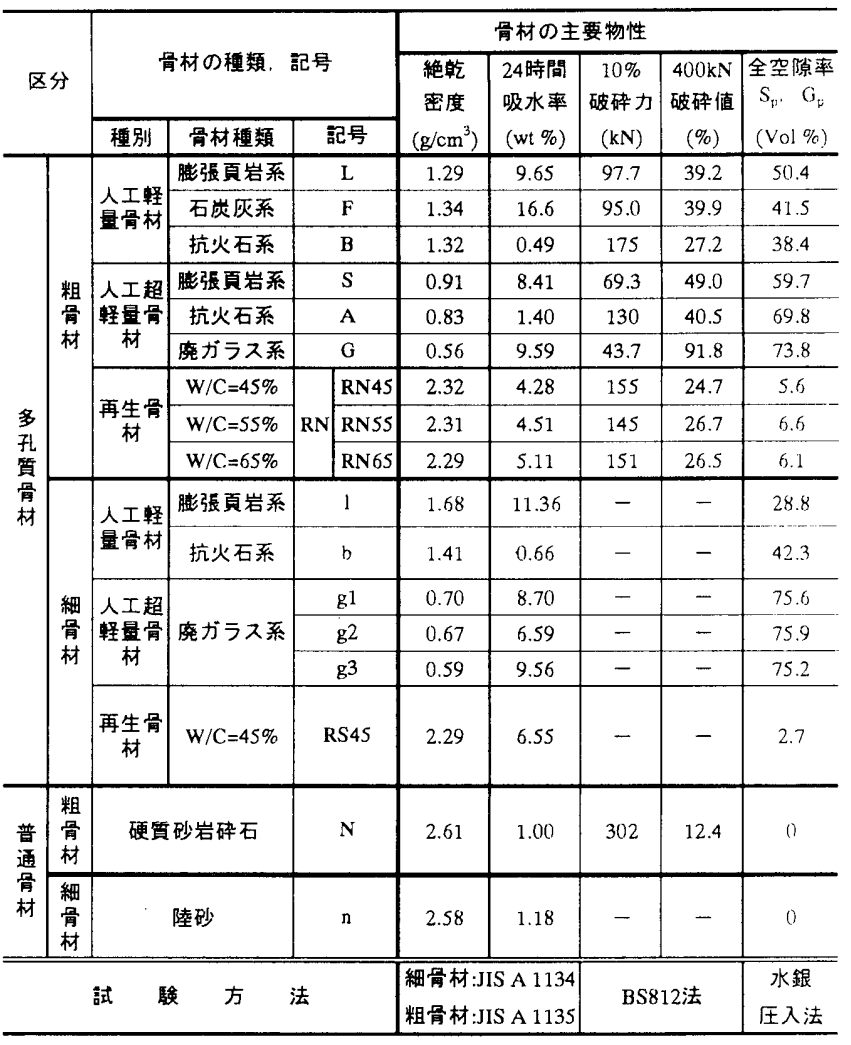

（1）シリーズIで使用した骨材の種類

原料構成, 製造方法, 密度, 吸水率, 強度, 表層シエルの有無等 の異なる 15 種類の多孔質骨材を対象とした。表 1 に骨材の主要物性 のうち, 空隙特性と高い相関が予測される密度, 吸水率, 強度上骨 材の容積に対する全空隙容積の割合を表す全空隙率(Vol\%) (以下, 紌 骨材については $\mathrm{S}_{\mathrm{p}}$, 粗资材については $\mathrm{G}_{\mathrm{p}}$ の記号で示す)を示す。

(2) 空隙測定用試料の調整

空隙測定用試料の調整：普通骨材，人工軽量骨材および人工超軽 量骨材にあって注，原則として粗骨材を $5 \mathrm{~mm}$ 角程度，細骨材を有姿 としたままに調整した。再生骨材にあっては，粗骨材に付着したも ルタル部分を $5 \mathrm{~mm}$ 角程度に採取したものを試料とした。

採取した普通骨材，人工軽量骨材および人工超軽量骨材の試料に

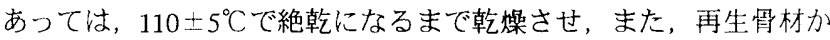
ら採取したモルタル試料にあっては，採取後直ちにアセトンに浸責 し，0.5，4 時間後にアセトンの交換を行い, 計 24 時間浸漬後, 直ち に真空ポンプ $\left(7.5 \times 10^{-3} \mathrm{mmHg}\right)$ にり 24 時間乾燥処理を行い, 空 隙の測定まで試験管内で密封保管した。

(3)空隙の測定方法

空隙の測定は，水銀圧入法（装置：FISION Instrument 社製杖ロシ メーターPascal 140 型および Pascal 240 型 最大圧力:200Mpa, 空隙 半径の測定範囲: $3.7 \mathrm{~nm} \sim 58,000 \mathrm{~nm}(58 \mu \mathrm{m}))$ によった。

本研究では，空隙径 $3.7 \mathrm{~nm} \sim 58 \mu \mathrm{m}$ 篨囲の空隙を対象としている。 3.2 シリーズ II III : モルタルの空隙特性とカ学的特性に関する研究 (1) 使用材料

セメントは普通ボルトランドセメントを用いた。骨材は表 1 に示 すうち，多孔質骨材として $\ell ， \mathrm{~g} 1 ， \mathrm{~g} 2 ， \mathrm{~g} 3 ， \mathrm{~b}$ ，普通骨材として， n また，普通婴材を含む再生骨材 RS45 の合計 7 種類を使用した。

化学混和剂は $\mathrm{W} / \mathrm{C}=35 \%$ 以下のモルタルにあっては, 高縮合トリア 
ジン采の高性能減水剤を使用した。

(2) 試料モルタルの種類, 調合概略および養生

試料モル夕ルは，細骨材種類の組み合せを 8 水準，W/C は 25\%, $30 \% ， 35 \% ， 45 \% ， 55 \% の 5$ 水準とした合計 35 種類である。モル夕 ルの種類および調合概略を表 2 に示す。脱型は打設終了時から 24 時 間後に行い, 2 次養生として水中養生 $\left(20 \pm 2^{\circ} \mathrm{C}\right)$ および気中養生 $(20 \pm$ $\left.2^{\circ} \mathrm{C}, \mathrm{RH} 60 \pm 5 \%\right) 02$ 水準とし, 試験材跘は28日とした。

(3) 検出特性值および試験方法

(a) 硬化したモルタルの力学的特性

モルタルの密度は供試体重量を容積で除して求めた。圧縮強度は JIS A 1108 に準拠して行った。ヤング係数はコンプレッソメーター法 により圧縮応力度の $1 / 3 の$ 点の割線剛性から求めた。

(b) モルタルの空隙用測定試料の調整および測定方法

モルタルの空隙測定用試料は，圧縮強度およびヤング係数測定用 0供試体と同一とした。王縮強度およびヤング係数を測定した 3 体 の供試体を直ちにコンクリートカッターにより，図 2 に示すように 供試体の上下面 $5 \mathrm{~cm}$ を取り除いた中央部を $\phi 10 \times 2 \mathrm{~cm}$ のディスク状 に切断し，外側から $2 \mathrm{~cm}$ と内側の箸囲に分けて，それぞれ採取し， 內部のものを測定に供した。測定までの調整方法は再生愲材から採 取した洰ルタル試料と同様な手順である。

以上の手順で調整されたモルタル中の全空隙容積は，3.1(3)に示す 方法で測定した。

3.3 シリーズII， III：コンクリートの空隙特性と力学的特性に

\section{関する研究}

(1) 使用材料

セメントは普通ポルトランドセメントを用いた。骨材は表 1 に示 すうち，粗骨材には多孔質骨材として，L，Sおよび G，普通骨材に 沈NO4 種類, 細骨材には多孔質骨材として, $\ell$ および粒度の異なる 3 種類の g1，g2，g3，普通骨材としてnの5種類を用いた。

化学混和剂には高縮合トリアジン系高性能減水剂, リグニンスル フォン酸系 $\mathrm{AE}$ 減水剤ならびに空気量調整剤（樹脂酸系）を使用し た。廃ガラス系細骨材を用いたコンクリートにあっては，水溶性セ ルロースエーテル系の分離低減剤を使用した。目標スランプ $19 \pm$ $1.5 \mathrm{~cm}$ となるように各種混和剂を調整して用いた。

\section{(2) 試料コンクリートの種類および調合概略}

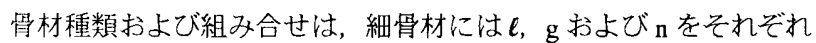
単味で使用し，粗骨材には L, S, G，およびNの 4 種類を単味，ま たは，容積混合して使用した。W/C は $25 \% ， 30 \% ， 35 \% ， 45 \% ， 55 \%$ ホよび $65 \%$ の 6 水準とした。以上のように計画した合計 45 種類の試 料コンクリートを作製した。表 3 に試料コンクリートの種類および コンクリートの全空隙率 $\left(V_{0} \ell \%\right)\left(C_{p}\right)$ の範囲を示す。

\section{(3) 養生および試験材蔽}

脱型法，打設終了時から 24 時間後に行い， 2 次養生法水中養生(20 $\left.\pm 2^{\circ} \mathrm{C}\right)$ 㧍よび気中養生 $\left(20 \pm 2^{\circ} \mathrm{C}, \mathrm{RH} 60 \pm 5 \%\right)$ の 2 水準とした。試験材 踰は 7 日，28 日および 91 日とした。なお，一部のコンクリートは， 材齢 1 年においても諸試験を行った。

（4）検出特性値および試験方法

(a) 硬化したコンクリートの力学的特性

コンクリートの密度, 圧縮強度抢よびヤング保数の測定は, シリ 一ズロと同様の方法で行った。
表 2 試料モルタルの種類および調合概略

\begin{tabular}{|c|c|c|c|c|c|c|c|c|c|c|}
\hline \multirow{2}{*}{ 種類 } & \multirow{2}{*}{$\begin{array}{c}\text { 試料 } \\
\text { モルタル } \\
\text { の } \\
\text { 記号 }\end{array}$} & \multicolumn{3}{|c|}{ 骨材の種類および組合わせ } & \multicolumn{5}{|c|}{$\mathrm{W} / \mathrm{C}(\%)$} & \multirow{2}{*}{$\begin{array}{c}\text { モルタルの } \\
\text { 全空率 }\left(\mathrm{M}_{\mathrm{p}}\right) \\
\text { の範囲 } \\
(\mathrm{Vol} \%)^{* 2}\end{array}$} \\
\hline & & \multicolumn{2}{|c|}{$\begin{array}{c}\text { 種類およひ } \\
\text { 組合わせ }\end{array}$} & $\begin{array}{c}\text { 混合率 }(\%) \\
\text { (容積比) }\end{array}$ & 25 & 30 & 35 & 45 & 55 & \\
\hline \multirow{4}{*}{$\begin{array}{c}\text { 多孔筫 } \\
\text { 骨材 } \\
\text { モル } \\
\text { タル } \\
\text { (シリー- } \\
\text { ズロ }\end{array}$} & M $\ell$ & \multirow{3}{*}{$\begin{array}{l}\text { 膨張頁 } \\
\text { 岩系 }(\ell)\end{array}$} & - & $\ell$ 単味 & 0 & 0 & 0 & 0 & 0 & $11 \sim 30$ \\
\hline & Meg & & $\begin{array}{c}\text { 廃ガラス } \\
\text { 系-g }{ }^{*}\end{array}$ & $\epsilon: g=50: 50$ & 0 & 0 & 0 & 0 & 0 & $18 \sim 37$ \\
\hline & $\mathrm{Meb}^{* 3}$ & & $\begin{array}{c}\text { 抗火石系 } \\
\text { b }\end{array}$ & $\ell: b=70: 30$ & 0 & 0 & 0 & 0 & 0 & $15 \sim 27$ \\
\hline & $\mathrm{Mg}$ & $\begin{array}{l}\text { 穈ガラ } \\
\text { ス系(g) }\end{array}$ & - & g单味 & 0 & 0 & 0 & 0 & 0 & $23 \sim 47$ \\
\hline \multirow{4}{*}{$\begin{array}{l}\text { 普通 } \\
\text { 骨材を } \\
\text { 含む } \\
\text { モル } \\
\text { タル } \\
\text { (シリー } \\
\text { ズIII) }\end{array}$} & $\mathrm{Mn}$ & \multirow{3}{*}{ 陸砂 $(\mathrm{n})$} & - & - & 0 & 0 & 0 & 0 & 0 & $9 \sim 16$ \\
\hline & Mne & & $\begin{array}{c}\text { 膨張頁岩 } \\
\text { 系 } \ell\end{array}$ & $\mathrm{n}: \ell=: 50: 50$ & 0 & 0 & 0 & 0 & 0 & $11 \sim 20$ \\
\hline & Mng & & $\begin{array}{c}\text { 廃ガラス } \\
\text { 系-g }\end{array}$ & $n: g=50: 50$ & 0 & 0 & 0 & 0 & 0 & $13 \sim 29$ \\
\hline & MRS & $\begin{array}{l}\text { 再生骨 } \\
\text { 材(RS) }\end{array}$ & - & RS単味 & 0 & 0 & 0 & 0 & 0 & $9 \sim 28$ \\
\hline
\end{tabular}

空隌測定用試料の採取範囲

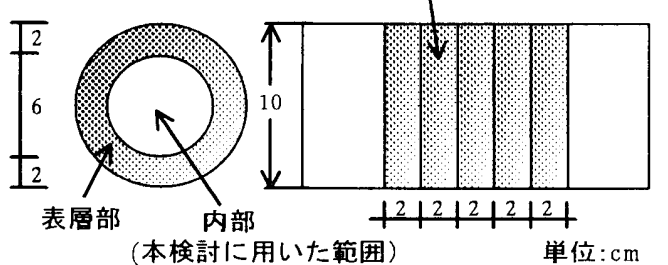

図 2 セメントペースト,モルタル,

コンクリートの空隙測定用試料の採取範囲

表 3 試料コンクリートの種類および調合概略

\begin{tabular}{|c|c|c|c|c|c|c|}
\hline \multirow[b]{3}{*}{ 種類 } & \multicolumn{5}{|c|}{ 試料コンクリートの種類 } & \multirow{3}{*}{$\begin{array}{c}\text { コンクリート } \\
\text { の全空隙率 } \\
(\text { Vol\% }) C_{p} \text { の } \\
\text { 範囲※2 }\end{array}$} \\
\hline & \multirow{2}{*}{$\begin{array}{l}\text { コンク } \\
\text { リート } \\
\text { の記号 }\end{array}$} & \multicolumn{3}{|c|}{ 粗骨材 } & 細骨材 & \\
\hline & & \multicolumn{2}{|c|}{ 種類および記号 } & $\begin{array}{l}\text { 混合率 } \\
(\mathrm{Vol} \%)\end{array}$ & 種類および記号 & \\
\hline \multirow{6}{*}{$\begin{array}{l}\text { 多孔質骨 } \\
\text { 材コンク } \\
\text { リート (シ) } \\
\text { リーズ II) }\end{array}$} & $\mathrm{Ll}$ & \multicolumn{2}{|c|}{ L:膨張頁岩系 } & L单味 & \multirow{3}{*}{$\begin{array}{c}\text { 1:膨張頁岩系 } \\
\text { 単味 }\end{array}$} & $28 \sim 38$ \\
\hline & $\mathrm{Sl}$ & \multirow{2}{*}{$\begin{array}{c}\mathrm{S}: \text { 膨張頁 } \\
\text { 岩系 }\end{array}$} & - & $S$ 単味 & & $29 \sim 42$ \\
\hline & SGI & & $\begin{array}{c}\mathrm{G}: \begin{array}{l}\text { 庤ガラス } \\
\text { 系 }\end{array} \\
\end{array}$ & $S: G=50: 50$ & & $31-35$ \\
\hline & $\mathrm{Lg}$ & \multicolumn{2}{|c|}{ L:膨張頁岩系 } & L単味 & \multirow{3}{*}{$\begin{array}{c}\mathrm{g}: \text { 廃ガラス系 } \\
\text { 単味※1 }\end{array}$} & $41-42$ \\
\hline & $\mathrm{Sg}$ & \multirow{2}{*}{$\begin{array}{c}\text { S:膨張頁 } \\
\text { 岩系 }\end{array}$} & - & $S$ 単味 & & $47 \sim 49$ \\
\hline & $\mathrm{SGg}$ & & $\begin{array}{c}\text { G:廃ガラス } \\
\text { 系 }\end{array}$ & $\mathrm{S}: \mathrm{G}=50: 50$ & & $44 \sim 66$ \\
\hline \multirow{5}{*}{$\begin{array}{c}\text { 普通骨材 } \\
\text { 含むコンク } \\
\text { リート } \\
\text { (シリーズ } \\
\text { III) }\end{array}$} & $\mathrm{Ln}$ & \multicolumn{2}{|c|}{ L:膨張頁岩系 } & L戦味 & \multirow{4}{*}{$\begin{array}{c}\mathrm{n}: \text { 陸砂 } \\
\text { 単味 }\end{array}$} & $16 \sim 31$ \\
\hline & $\mathrm{Sn}$ & \multirow{2}{*}{$\begin{array}{c}\mathrm{S}: \text { :膨張頁 } \\
\text { 岩系 }\end{array}$} & - & S単味 & & $22 \sim 38$ \\
\hline & SGn & & $\begin{array}{c}\mathrm{G}: \text { 廃ガラス } \\
\text { 系 }\end{array}$ & $S: G=50: 50$ & & $23 \sim 38$ \\
\hline & $\mathrm{Nn}$ & \multirow{2}{*}{\multicolumn{2}{|c|}{$\mathrm{N}$ :硬質砂岩砕石 }} & \multirow{2}{*}{$\mathrm{N}$ 単味 } & & $0.7 \sim 39$ \\
\hline & $\mathrm{Nl}$ & & & & $\begin{array}{c}\text { 1:膨張頁岩系 } \\
\text { 单味。 }\end{array}$ & $7 \sim 18$ \\
\hline
\end{tabular}

※1 表中のgは, g1:g2: $93=5: 4: 3$ の容積比で湿合便用したものの総称

※2 W/C=25\%〜 55\%のモルタルにおける範囲を示したものである。

(b) コンクリートの空隙用測定試料の調整および測定方法

硬化したコンクリートの空隙測定用試料は, 図 2 に示す範囲から,

コンクリート中のモルタル部分のみを採取し，空隙の測定を行った。

なお，空隙测定用試料の採取から測定までの調整方法こついても

モルタルの場合と同様である。

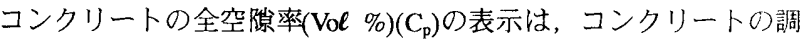
合からモルタルと粗骨材の容積比を求め，(6)式に示すようにコンク リート容積に対する全空隙容積とシリーズIで測定した骨材容積に 
対する空隙容積の和をコンクリートの全空隙率とした。

なお，(6)式は，コンクリートの練り上がり密度は計画調合から求 まるコンクリートの密度に対して, JASS 516 節 軽量コンクリート において許容範囲とされる $3.5 \%$ 範囲内にあることを検証したう えで採用されるものである。

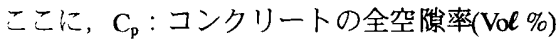

$C_{p}=\frac{\left(X \times{ }_{M} V_{p}\right)+\left(Y \times_{G} V_{p}\right)}{{ }_{c} V} \times 100(\mathrm{Vol} \%) \quad(6)$ 式

$\mathrm{v}:$ :コンクリートの全容積 $\left(\mathrm{m}^{3}\right)$

${ }_{\mathrm{M}} \mathrm{V}_{\mathrm{p}}$ : 単位モルタル容積中の空隙容積 $\left(\ell / \mathrm{m}^{3}\right)$

${ }_{\mathrm{C}} \mathrm{V}_{\mathrm{p}}$ :単位多孔質粗骨材容積中の空隙容積 $\left(\ell / \mathrm{m}^{3}\right)$

$\mathrm{X}$ :単位コンクリート中のモルタルの容積比

$\mathrm{Y}$ 単位コンクリート中の多孔質粗情材の容積比

ただし, ${ }_{M} \mathrm{~V}_{\mathrm{p}}={ }_{\mathrm{p}} \mathrm{V}_{\mathrm{p}}+{ }_{\mathrm{s}} \mathrm{V}_{\mathrm{p}}$

${ }_{\mathrm{p}} \mathrm{V}_{\mathrm{p}}$ : 単位セメントペースト容積中の空隙容積 $\left(\ell / \mathrm{m}^{3}\right)$

${ }_{\mathrm{s}} \mathrm{V}_{\mathrm{p}}$ : 単位多孔質細骨材容積中の空隙容積 $\left(\boldsymbol{l} / \mathrm{m}^{3}\right)$

$\mathrm{X}+\mathrm{Y}=1$

$X=\frac{V_{p}+V_{s}}{V_{c}}, Y=\frac{V_{G}}{V_{c}}$

4. シリーズI : 多れ筫骨材の空隚特性に関する実験結果および検討 4.1 多孔質骨材の空隙特性

(1) 多孔質骨材の全空隙率

表 1 に各種多孔質骨材の全空隙率を示す。全体として, 全空䏚率は 骨材種類により多様に異なり，幅広い結果を示した。全空隙率が最 も小さい値を示したものは再生骨材であり，全体として $3 V_{0} \ell \%$ 7 Vol \%の範囲にある。現在, 構造用人工軽量骨材として使用されて

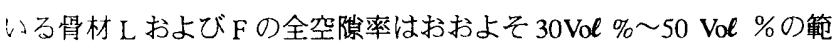
国にある。また，骨材 B の全空隙率は骨材 L および F の值に近く， $38.4 \mathrm{~V} 0 \ell \%$ \%ある。人工超軽量骨材 $\mathrm{S}, \mathrm{G}$ および A の全空䏚率は，骨 材 $\mathrm{L}$ および $\mathrm{F}$ に比べ大きく $50 \mathrm{Vo \ell} \%$ 76Vol \%の範囲にある。なお，

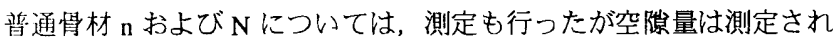
なかったことから，0Vo％として整理した。

(2) 多孔質骨材の空隙径分布

図 3 に多孔質骨材の空隙径分布の一例を示す。全空䏚率がほぼ同 じであっても，骨材種類により，ピークとなる径およびその数等の 空腙径分布は多様に異なることが確認できる。

\section{2 多孔筫骨材の空隙特性と従来の品筫評価項目の関係}

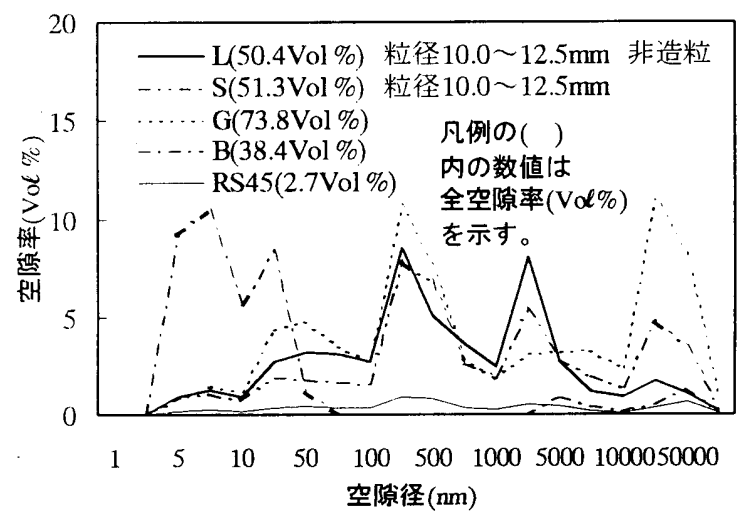

图 3 多孔筫骨材の空隙径分布の一例
本研究では，多孔質骨材の物性のうち，空隙特性と関連が梁い上 予測される密度, 吸水率および強度との相関を求めた。

表 4 に多孔質骨材の全空隙率と密度, 24 時間吸水率および強度の 関係から得られた回帰式を示す。これによると, 密度および強度特 性值である 400kN 破研値および 10\%破砕力は骨材の全空隙率と高い 相関性を示すことが認められた。24時間吸水率については, 全空隙 率との相関性は小さいが圧力吸水率では相関性は高いと予想される。

表 4 多孔質骨材の空陌特性と従来の品質評価項目の関係

\begin{tabular}{c|l|c}
\hline \multicolumn{1}{c|}{ 骨材の物性 } & \multicolumn{1}{|c|}{ 回帰式 } & 相関係数: $\gamma$ \\
\hline 絶乾密度 $\left(\mathrm{g} / \mathrm{cm}^{3}\right): \rho_{\mathrm{d}}$ & $\rho_{\mathrm{d}}=-0.025 \times\left(\mathrm{S}_{\mathrm{p}}, \mathrm{G}_{\mathrm{p}}\right)+2.40$ & -0.970 \\
\hline 24 時間吸水率 $(\mathrm{wt} \%): \mathrm{Q}$ & $\mathrm{Q}=1.65 \ln \left(\mathrm{S}_{\mathrm{p}}, \mathrm{G}_{\mathrm{p}}\right)+1.90$ & 0.700 \\
\hline $10 \%$ 破砕力 $(\mathrm{kN}): \mathrm{S}_{10}$ & $\mathrm{~S}_{10}=249 \mathrm{e}^{-0.026 \mathrm{~g}}$ & -0.966 \\
\hline $400 \mathrm{kN}$ 破砕値 $(\%): \mathrm{S}_{400}$ & $\mathrm{~S}_{400}=17.2 \mathrm{e}^{-0.025 \mathrm{Gp}}$ & -0.939 \\
\hline
\end{tabular}

5. シリーズII：多孔質骨材モルタル、コンクリートの 空膛特性と力学的特性に関する実験結果および険討

5.1 多孔筫骨材モルタル，コンクリートの全空隙率と密度の関係

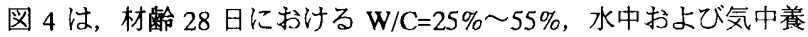
生とした 35 種類の多孔質骨材モルタルと $\mathrm{W} / \mathrm{C}=25 \%$ ～65\%，水中養 生および気中養生，材齢 7 日，28 日および長期材齢(材踰 91 日およ び 1 年) とした合計 160 種類の多孔質骨材コンクリートの全空隙率と 密度の関係を示したものである。

これによると，両者の関係は，全空隙率が大きくなるに伴い，密度 注直線的に小さくなり，モルタル，コンクリートの順に，相関係数 $-0.944 ，-0.868$ の比較的高い相関性の直線式により回㷌される。

しかし, 雨者の関係には若干のばらつきが認められ, 本研究で対象 とした空隙径より大きい気泡，また骨材種類，材齢，養生方法によ り異なるマトリクス中の含水率の影響を考慮することで高まること が予測される。

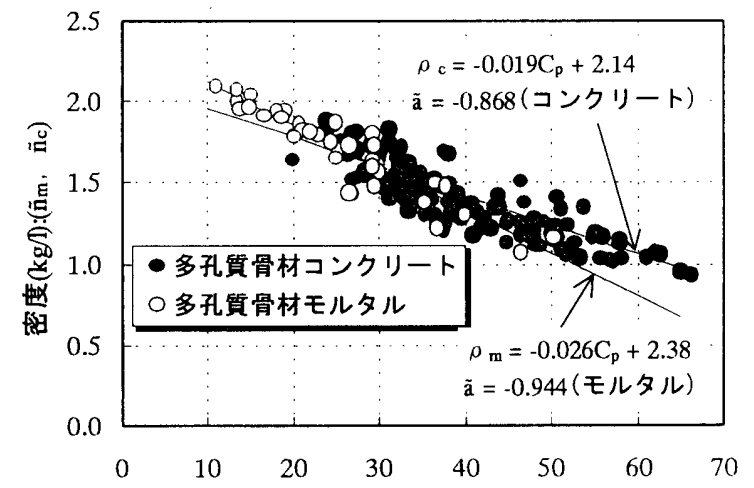

多孔質骨材モルタル，コンクリートの全空隙率 $(\mathrm{V} o \ell \%):\left(\mathrm{M}_{\mathrm{p}}, \mathrm{C}_{\mathrm{p}}\right)$ 図 4 多孔質骨材モルタル,コンクリートの全空隙率と密度の関係

5.2 多孔筫骨材モルタル,コンクリートの全空隙率と圧縮強度の関係

(1) 多孔質骨材モルタルの全空䍀率と圧縮強度の関係

図 5 に材路 28 日における 35 種類の多孔質骨材モル夕ルの全空隙 率と圧縮強度の関係を示す。これによると，骨材種類，水セメント 比, 養生方法によらず，両者の関係は，相関係数 -0.945 の指数関数 式により回帰されることが確認できる。

（2）多孔質骨材を用いたコンクリートの全空隙率と圧縮強度の関係 図 6 は, W/C=25\% 65\%, 材路 7 日，28 日および長期材齢（91日， 
1 年)における合計 160 種類の多孔質骨材コンクリートの全空隙率と 玨縮強度の関係を示したものである。これによると, 両者の関係か ら得られた回帰式の相関係数は， -0.764 上小さく，全空隙率が小さ くなることに伴う圧縮強度の增進割合は, 多孔質骨材モルタルに比 ベて小さい。これは，細骨材に比べ表面積の大きい粗骨材とセメン トベースト界面の付着性状が圧縮破壊に及ぼす影響が大きいためと 考えられる。

そこで，以下に，骨材界面の付着性状に影響を及ぼす水セメント 比，材齢に着目して，コンクリートの圧縮強度の評価指標としての 全空隙容積の適用性について検討を行った。

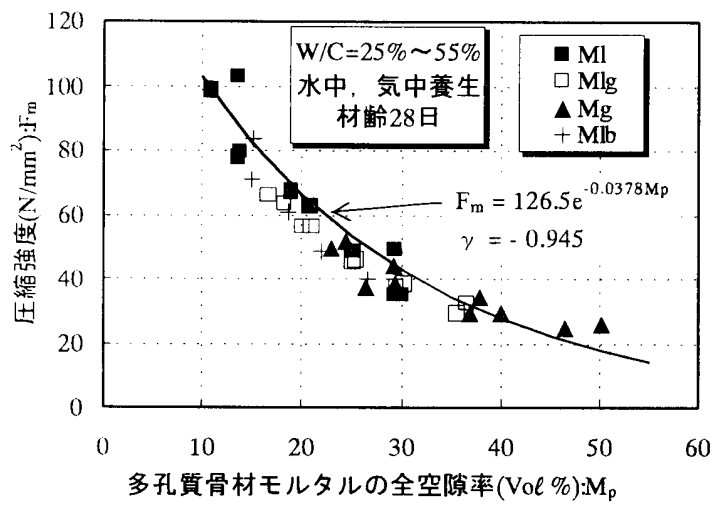

図 5 多孔質骨材モルタルの全空隙率と圧縮強度の関係
(2-1) 水セメント比の影響

図 7(a)および図 7(b)は, 水セメント比別に多孔質骨材コンクリート の全空隙率と圧縮強度との関係を示したものである。これらによる と， $\mathrm{W} / \mathrm{C}=25 \%$ 35\%とした場合では，両者の関係は多孔質體材モル タルと同様であり，相関係数 -0.880 の指数関数式により回帰される。 また, $\mathrm{W} / \mathrm{C}=45 \%$ 以上の場合では, 両者の相関性は小さく，その傾向 は，水セメント比の增加に伴い顕著となる。

(2-2) 材齢の影響

図 8(a)～図 8(c)は多孔質骨材コンクリートの全空隙率と圧縮強度 の関係を材齢別に示したものである。これによると，両者の相関性 は，材龄の経過に伴い高まり，また，その関係も多孔質骨材モル夕 ルの場合と類似することが確認できる。

以上の検討から，多孔質骨材モルタルおよびコンクリートの全空 隙率と圧縮強度の相関性は，水セメント比が小さく，また長期材齡 になるに伴い高まり, 材齢 91 日以降では, モルタル, コンクリート の両者の関係は類似することが確認された。このことは, 低水セメ ント比，長期材路のものほど，べーストと骨材界面の付着性状が压 縮強度へ及ぼす影響が小さいことを示唆するものと考光られる。

5.3 多孔筫骨材モルタルおよびコンクリートの全空隙率と ヤング係数の関係

図 9 は, 材踰 28 日における 35 種類の多孔質骨材モル夕ルと材齢 7 日，28日および長期材㱓(材齢 91 日および 1 年)における 160 種類の)

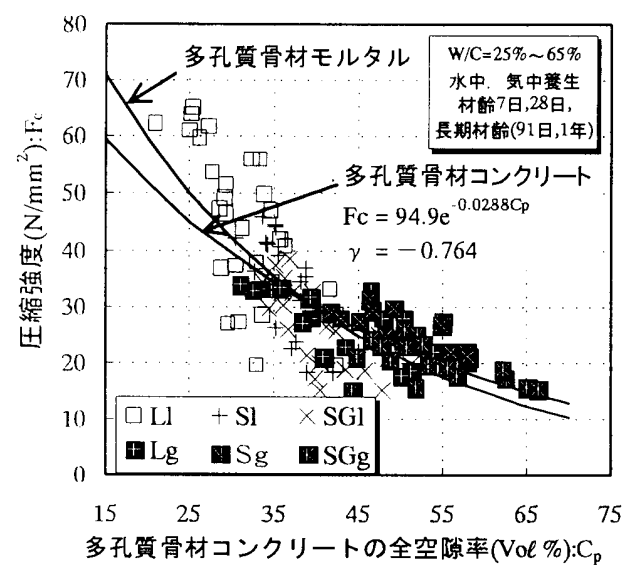

図 6 多孔筫骨材コンクリートの 全空隙率と圧縮強度の関係

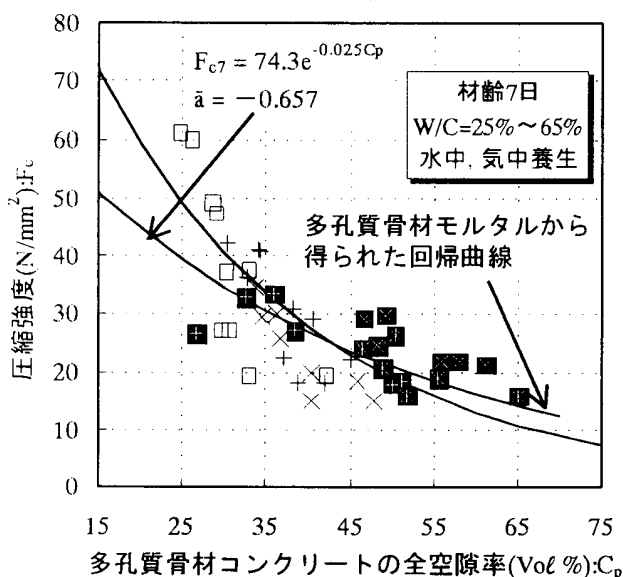

図 8(a) 材齢 7 日

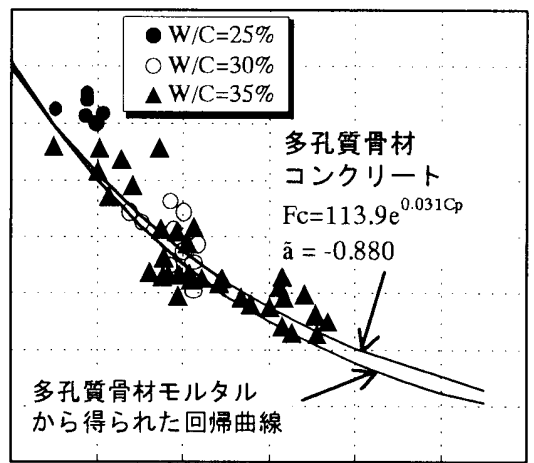

$\begin{array}{lllllll}15 & 25 & 35 & 45 & 55 & 65 & 75\end{array}$ 多孔質骨材コンクリートの全空陌率 $\left(V_{0} \ell \%\right): \mathrm{C}_{\mathrm{p}}$

图 7(a) 水セメント比 $25 \%, 30 \%, 35 \%$ 图 7(a)，(b) 多孔䝷骨材コンクリートの全空隙率と圧縮強度の関係(水セメント比別)
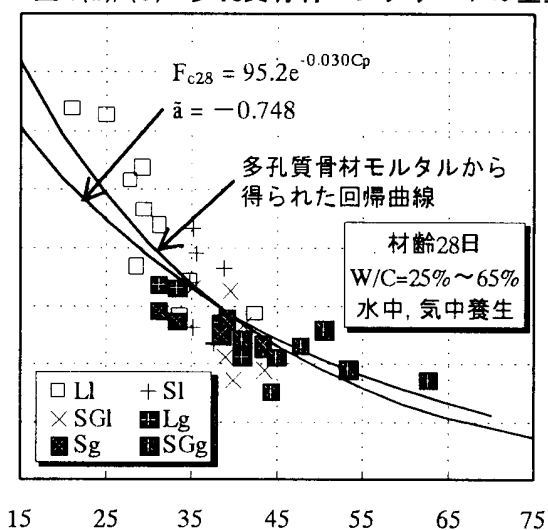

多孔質骨材コンクリートの全空隙率 $\left(V_{o} \ell \%\right): C_{p}$ 図 8(b) 材歯 28 日

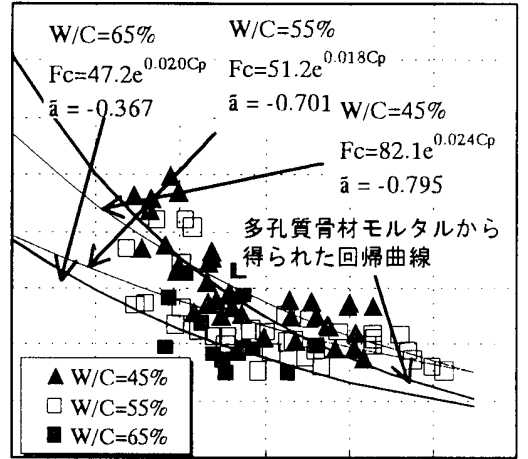

$\begin{array}{lllllll}15 & 25 & 35 & 45 & 55 & 65 & 75\end{array}$

多孔質骨材コンクリートの全空陌率 $(\mathrm{Vol} \%): \mathrm{C}_{\mathrm{p}}$ 图 7(b) 水セメント比 45\%, 55\%,65\%

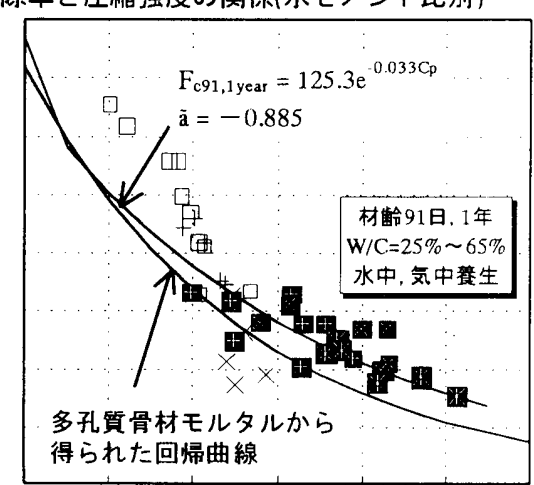

$\begin{array}{lllllll}15 & 25 & 35 & 45 & 55 & 65 & 75\end{array}$

多孔質骨材コンクリートの全空隙率( Vol\%): $C_{p}$ 図 8(c) 材路 91 日，1年

図 8(a)，(b)，(c) 多孔質骨材コンクリートの全空隙率と圧縮強度の関係(材齢別) 
多孔質骨材コンクリートの全空隙率とヤング係数の関係を養生方法 別に示したものである。

これによると，両者の関倸は養生方法により若干異なるが，全体 として，高い相関性の指数関数式で回帰されることが確認される。

水中養生とした多孔質骨材モルタル，コンクリートで注気中養生 とした場合に比べ，同一の全空隙率に対するヤング係数が若干大き いことが確認され，このことは，密度と同様に養生方法，材跲等に よるマトリクスの含水率による影響であると考えられる。

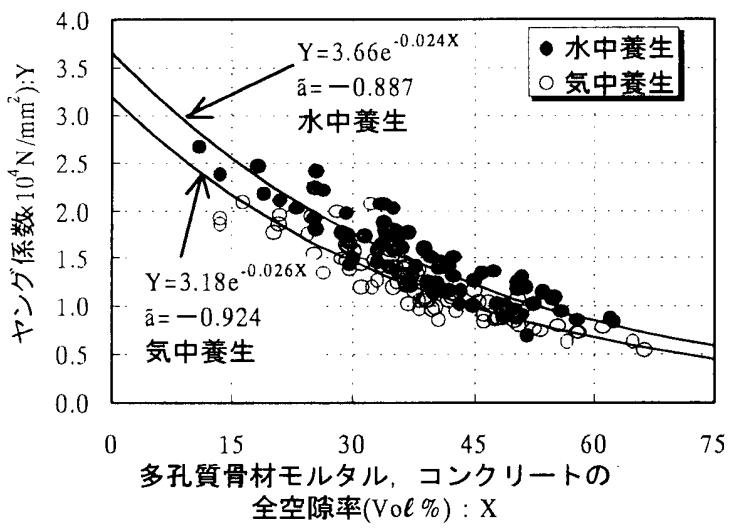

図 9 多孔質骨材モルタル,コンクリートの全空䟢率とヤング係数の関係

6. シリーズIII : 普通骨材と多孔質骨材を用いたモルタル、コンクリ 一トの空隌特性と力学的特性の関係に関する実験結果および検討

6.1 普通骨材と多孔筫骨材を用いたモルタル，コンクリートの 全空隙率と密度の閏係

図 10 に，普通骨材と多孔質骨材を用いたモルタル，コンクリート 0)全空隙率と密度の関倸を, シリーズ】における多孔質骨材モル夕 ル，コンクリートを併せ示す。これによると，両者の関倸は，全体 で, 相関係数 -0.962 の直線式で回帰されることが確認される。

また，同一全空隙率に対する密度は，水中養生とした場合に掠い て若干大きく，このことは，全空隙率の大きい場合に顕著になる傾 间であることが確認できる。

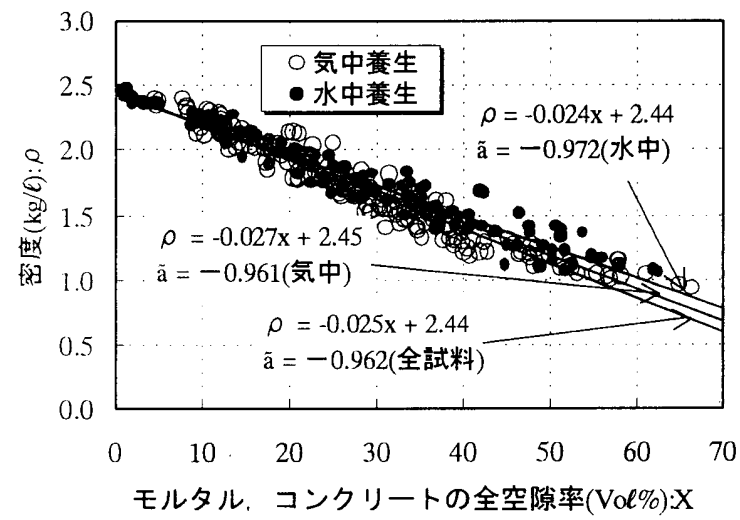

図 10 モルタル，コンクリートの全空陌率と密度の関係

6.2 普通骨材と多孔筫骨材を用いたモルタル，コンクリートの 全空隙率と圧縮強度の関係

図 11 および図 12 に普通骨材のみ，あるいは普通骨材と多孔質骨 材を用いたモルタル，コンクリートの全空隙率と圧縮強度の関係を 示す。なお，図中には，多孔質骨材モルタルより得られた回帰式も 示す。これらによると，モルタルの全空隙率と珐縮強度の関係は，

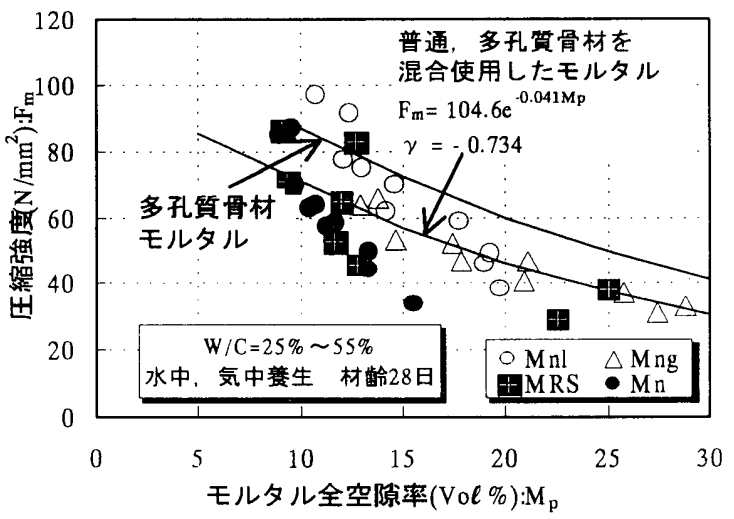

図 11 普通骨材と多孔質骨材を用いたモルタルの全空隙率と圧縮強度の関係

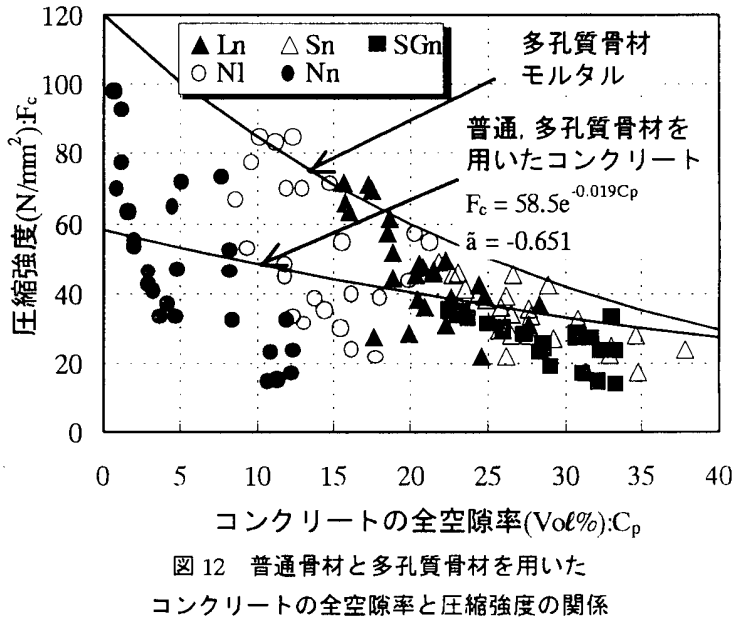

相関係数 -0.73 コンクリートでは, 相関係数 -0.651 と小さい。 既往の研究において，鎌田 1)らは，普通骨材を用いたコンクリ一 トの圧縮強度を空隙特性により推定する際，ペースト中の全空隙容 積に着目した空隙特性として有効細孔量を(7)式により求め, これを 圧縮強度の推定のためのひとつの指標として採用している。

$$
\text { 有效細孔量 }(c c / g)=\frac{{ }_{p} V_{p}}{{ }_{p} W} \quad(7) \text { 式 }
$$

ここに, $\mathrm{p} W$ : 単位セメントペーストの重量 $(\mathrm{g})$

しかし，(7)式は，ペースト部の空隙のみを扱ったものであり，多 孔質骨材中の空隙容積については対象としていない。

そこで，本研究では，(7)式を参考として，普通骨材と多孔質骨材 を用いたコンクリートの圧縮強度を推定するための空隙特性として 有効全空隙率 $\left(\mathrm{C}_{\mathrm{e} p}\right)$ を(8)式により求め，これと圧縮強度との相関性在 求めた。なお，普通骨材之多孔質骨材を用いたモルタルの場合につ いても同様な方法により求めた有効空隙率 $\left(\mathrm{M}_{\mathrm{ep}}\right)$ を用いて圧縮強度と の相関を求めた。

$C_{e p}=\frac{\left(X \times{ }_{p} V_{p}\right)+\left(Y_{2} \times{ }_{s} V_{p}\right)+\left(Z_{2} \times{ }_{G} V_{p}\right)}{{ }_{p} V+{ }_{s} V+{ }_{G} V} \times 100(\mathrm{Vol} \%) \quad$ (8)式 ここに， $\mathrm{C}_{\mathrm{ep}}$ ：普通骨材と多孔質骨材を混合使用したコンクリート の有効全空隙率(Vol\%) cV:普通骨材と多孔質骨材を用いたコンクリートの全容積 $\left.\mathrm{m}^{3}\right)$ ${ }_{\mathrm{p}} \mathrm{V}:$ セメントペーストの絶対容積 $\left(\ell / \mathrm{m}^{3}\right)$ ${ }_{s} \mathrm{~V}:$ 多孔質細骨材の絶対容積 $\left(\ell / \mathrm{m}^{3}\right)$ ${ }_{\mathrm{G}} \mathrm{V}:$ 多孔質粗骨材の絶対容積 $\left(\ell / \mathrm{m}^{3}\right)$ ${ }_{\mathrm{p}} \mathrm{V}_{\mathrm{p}}$ : 単位セメントペースト容積中の空隙容積 $\left(\ell \mathrm{m}^{3}\right)$ 
,$V_{p}$ :単位多孔質細骨材容積中の空䍀容積 $\left(\ell / \mathrm{m}^{3}\right)$ ${ }_{G} \mathrm{~V}_{\mathrm{p}}$ :単位多孔翼粗骨材容積中の空隙容積 $\left(\ell / \mathrm{m}^{3}\right)$ $\mathrm{X}$ : 単位コンクリート中のセメントペーストの容樌比

$\mathrm{Y}_{1}$ : 単位コンクリート中の普通細骨材の容積比

$Y_{2}:$ 単位コンクリート中の多孔質細骨材の容積比

$Z_{1}$ : 単位コンクリート中の普通粗冒材の容積比

$\mathrm{Z}_{2}$ : 単位コンクリート中の多孔質粗骨材の容積比

ただし, $X+Y_{1}+Y_{2}+Z_{1}+Z_{2}=1$

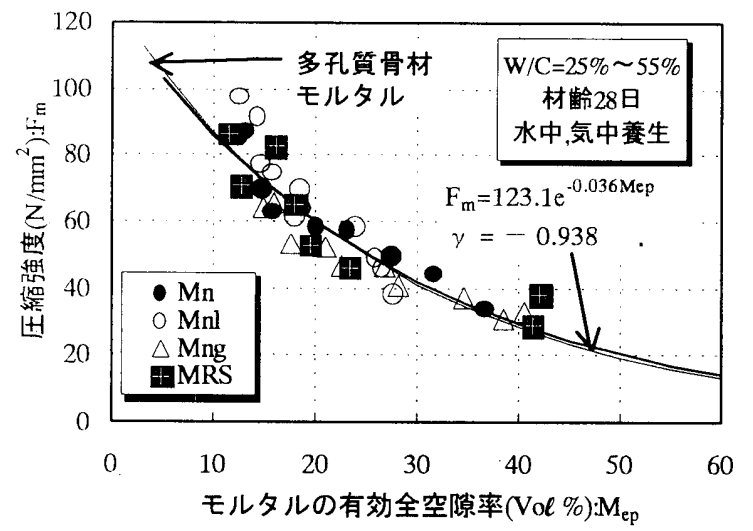

図 13 普通骨材と多孔筫骨材を混合使用した モルタルの有効全空隙率と圧縮強度の関係
図 13, 図 14 沙普通骨材と多孔質骨材を用いたモル夕ルおよびコン クリートの有効全空隙率と圧縮強度の関係を示したものである。

図 13 より, モル夕ルの両者の関係は, 相関係数 -0.938 の指数関数 式で回帰され，また，多孔質骨材モル夕ルの場合と同様な関係であ ることが確認される。

一方，図 14 より，コンクリートにあっては，有効全空隙率と玨縮 強度の相関性は，相関係数は一0.759 と図 12 に示した全空隙率の場 合と比較して，若干高まることが確認できる。しかし，粗骨材に普 通骨材を用いた $\mathrm{N} \ell$ および $\mathrm{Nn}$ コンクリートにあっては，有効全空隙 率が小さくなることに伴う圧縮強度の増加割合が多孔質骨材モル夕 ルの場合に比べ小さいといえる。

この理由には, シリーズ【の多孔質骨材コンクリートの場合と同様 に，細骨材に比べ表面積の大きい粗骨材界面の付着性状が圧縮破填 に及ぼす影響が大きく，特にセメントベーストに比べ強度，㴊性の 大きい普通骨材において顕著であると考えられる。

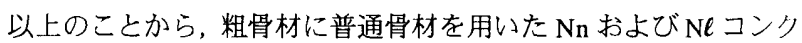
リートの㴼強度は，コンクリート中の空隙容積に比ベ普通粗骨材 界面の付着性状の影響が大きいことから，空隙特性のみによる圧縮 強度の評価は適切でないと判断し，これらコンクリートについては 以下の検討の対象から外し，骨材界面の付着性状に影響を及ぼす水 セメント比，材齢の影響に着目して検討を行った。

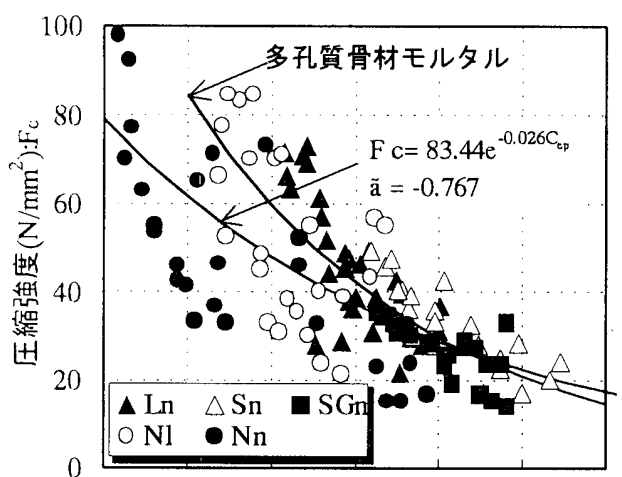

$\begin{array}{lllllll}0 & 10 & 20 & 30 & 40 & 50 & 60\end{array}$

図 14 普通骨材と多孔筫骨材を用いた コンクリート全空隙率と圧縮強度の関係

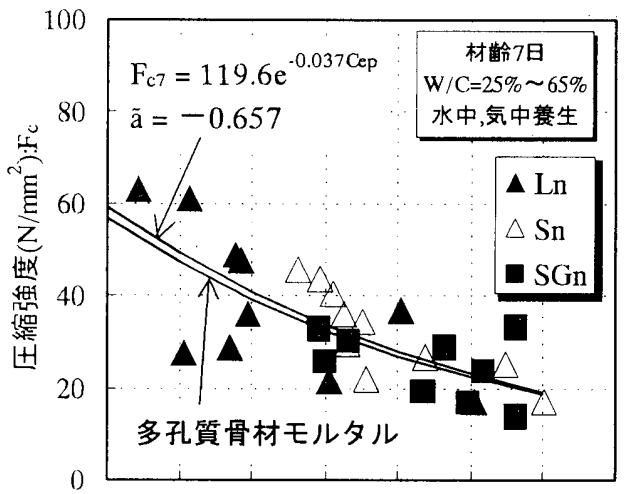

$\begin{array}{llllllllllllllll}20 & 25 & 30 & 35 & 40 & 45 & 50 & 55 & 20 & 25 & 30 & 35 & 40 & 45 & 50 & 55\end{array}$ コンクリートの有効全空隙率 $(\mathrm{Vo} \ell \%): \mathrm{C}_{\mathrm{ep}} \quad$ コンクリートの有効全空隙率 $\left(\mathrm{V}_{\mathrm{\ell}} \%\right): \mathrm{C}_{\mathrm{ep}}$ 図 16 (a) 材齢 7 日

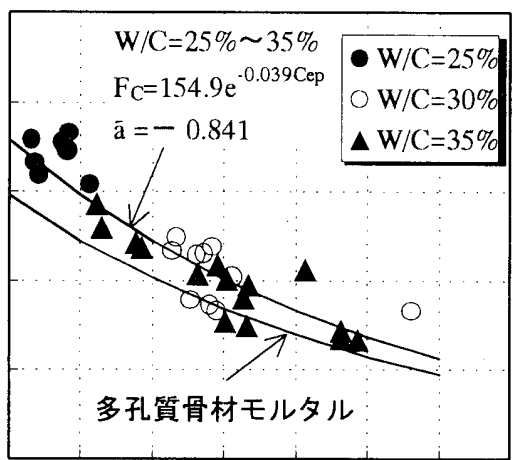

図 $15 \quad$ (a) $\mathrm{W} / \mathrm{C}=25 \% \sim 35 \%$

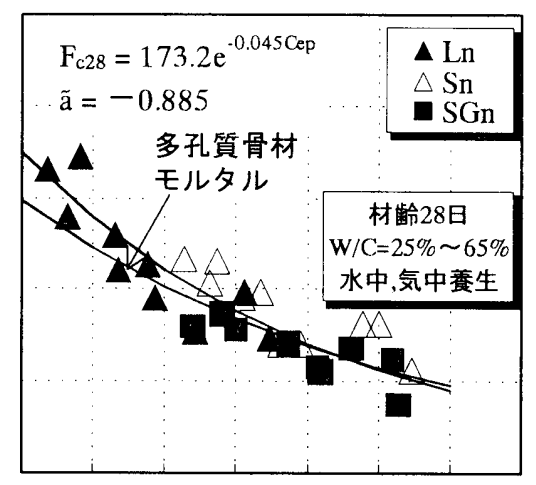
图 16 (b) 材齢 28 日

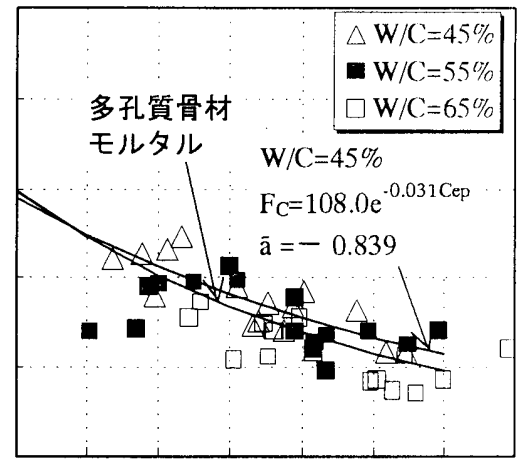

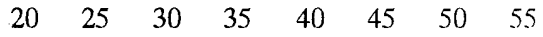

図 15 (b) $\mathrm{W} / \mathrm{C}=45 \% \sim 65 \%$

図 15 (a)〜(b) 普通骨材と多孔筫骨材を用いた コンクリートの有効全空隙率と圧縮強度の関係(水セメント比別)

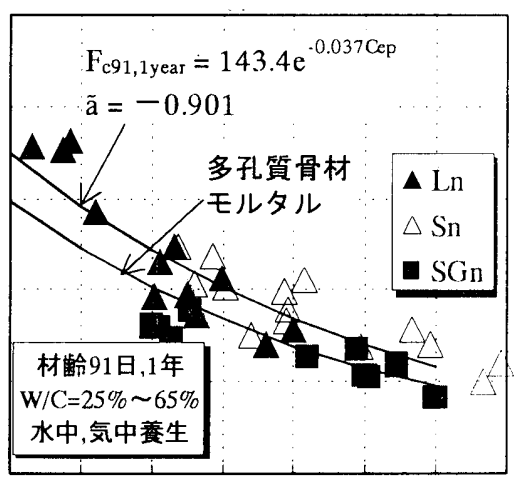

$\begin{array}{llllllll}0 & 25 & 30 & 35 & 40 & 45 & 50 & 55\end{array}$ コンクリートの有効全空隍率 $(\mathrm{Vo} \ell \%): \mathrm{C}_{\text {ep }}$ 図 16 (c) 材齢 91 日，1年

図 16 (a)〜 (c) 普通骨材と多孔筫骨材を用いたコンクリートの有效全空隙率と圧縮強度の関係(材齢別) 


\section{（1）水セメント比の影響}

眓 15(a)および図 15(b)はW/C=25\%〜35\%の範囲とW/C=45\%〜 55\% の)範囲にコンクリートを区分し，有効全空隙率と圧縮強度の関係を 示したものである。図 15(a)によると, W/C=25\%〜35\%の場合では, 絊骨材に普通骨材，粗骨材に多孔質骨材を用いたコンクリートの両 者の関係は，相関係数 -0.841 の指数関数式により回帰され，また， 多孔質骨材モルタルの場合と同様な関係であることが確認できる。

--方，図 15(b)によると，W/C=45\%〜55\%の場合では，両者の相関 性法小さく，また，多孔質骨材モルタルの場合と比較して，有効全 沙隙率に対する圧縮強度は若干小さくなることが確認される。

\section{(2) 材齢の影響}

図 16(a)〜図 16(c)恃普通骨材のみを用いた，または，普通骨材と 多孔質骨材を用いたコンクリートの有効全空隙率と圧縮強度の関倸 について，材齢別に示したものである。これらによると，粗骨材に 多孔質骨材，細骨材に普通骨材を用いたコンクリートの両者の相関 性は，材踰の経過に伴い相関性は高くなり,材齢91 日以降においては， 相関係数 -0.901 の指数関数式により回帰されることが確認できる。

以上の検討から，細肾材に普通查材，粗骨材に多孔質骨材を用いた コンクリートの材齢 91 日以降における圧縮強度の評価指標としてコ ンクリートの全容積の除いた容積に占める全空隙容積の割合とした 有効全空隙率の妥当性が確認された。

6.3 普通骨材と多孔筫骨材を用いたモルタルの全空隙率と ヤング係数の関係

図 17 に普通骨材のみ，また㹥普通骨材と多孔質骨材を用いたモル 夕ルの全空际率とヤング係数の関係を示す。これによると，両者の 関係法，相関係数 -0.939 0)指数関数式で回帰され，多孔質骨材モル タルの場合と同様な関係にあることが確認できる。

6.4 普通骨材および多孔筫骨材を用いたコンクリートの全空隙率と ヤング係数の関係

図 18 に普通骨材のみを用いた，または普通骨材および多孔質骨材 を用いたコンクリートの全空隙率とヤング係数の関係を示す。これ によると，全体として，両者の関係は多孔質骨材モル夕ルの場合と 類似するが，相関係数は一0.789 と小さい。詳細にみると， $\mathrm{N} \ell$ および $\mathrm{Nn}$ の一部において，ばらつきが大きいことが確認できる。

これは，乾燥などにより愲材界面に微細なクラックが生じたこと による㴊性低下が理由として考えられる。このことを考虑して，気 中養生，W/C=45\%以上とした $\mathrm{N}$ および $\mathrm{Nn}$ を除いた場合の両者の関 係にあっては，相関係数一0.902の高い相関を示すことが確認された。

\section{7. 結論}

多孔質骨材を用いたコンクリートにおける硬化体中の空隙特性と 力学的特性の関係を明らかにすることを目的に，多孔質骨材の空隙 特性ならびにモルタルおよびコンクリートの空隙率，圧縮強度，ヤ ング係数を測定した。その結果から大要以下のことがいえる。

（1）多孔質骨材の組成分，原料構成，製造方法，内部および表層の 構造等の相違は，全空隙率，空䧊径分布等の空隙特性に大きな影響 を及ぼすことが確認できた。

（2）多孔質骨材を用いたモル夕ルおよびコンクリートのうち，全空 隙率の大きいもの，水セメント比が $55 \%$ 以下のもの，材齢が 91 日を 越えるものについては, 養生方法の如何を問わず, 全空隙率と密度,

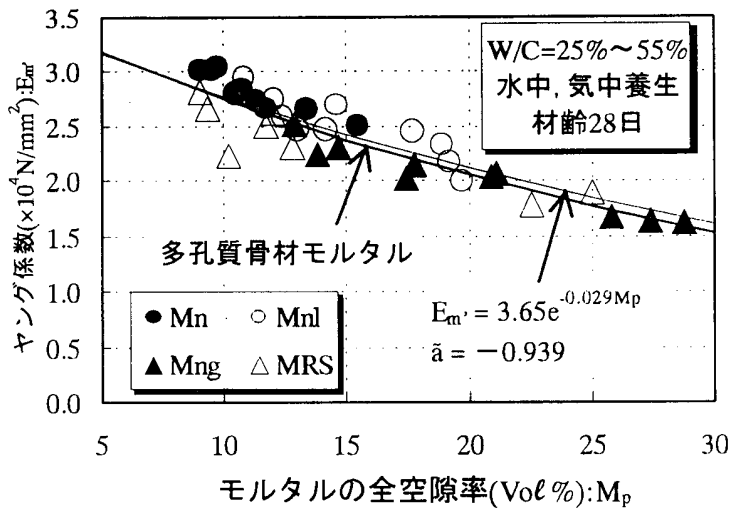

図 17 普通骨材と多孔筫骨材を用いた モルタルの全空隙率とヤング係数の関係

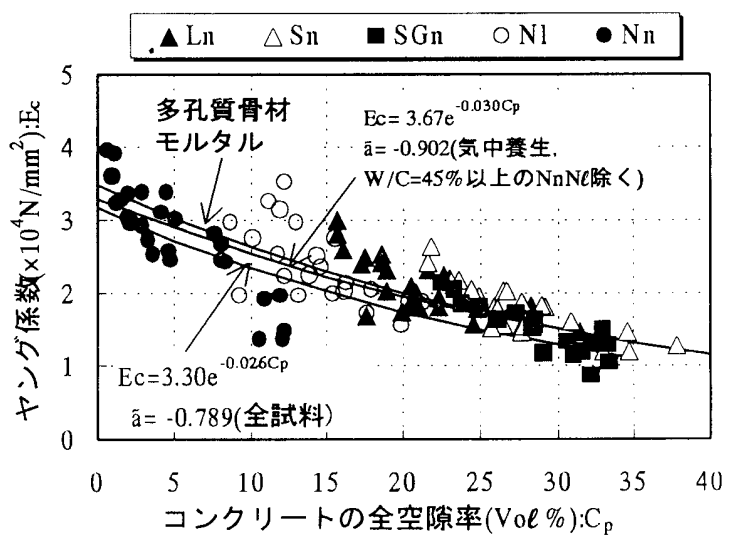

图 18 普通骨材と多孔筫骨材を用いた コンクリートの全空隙率とヤング係数の関係

圧縮強度，ヤング係数との間に高い相関性が認められた。

（3）普通骨材を含む全空隙率の小さなモルタルおよびコンクリート のうち，細骨材に普通骨材，粗骨材に多孔質骨材を用いたコンクリ 一トにあっては，水セメント比 55\%以下，材齢 28 日以上のものにつ いて，養生方法を問わず，密度，ヤング係数は全空你率上，圧縮強 度は，コンクリート全容積から普通骨材容積を除いた容積に占める 空隙の割合とした有効全空隙率との間に高い相関性が認められた。

（4）現在，これらの結果をもとに，骨材の一般的な物性と空腙特性 の関係をより精度良く解明し，それを代替特性値とすることにより 材料設計への移行を図る研究を行っている。

【謝辞】

本研究の実施にあたりまして，日本メサライト工業（株），クリスタ ルクレイ (株)，（株）新島物産，(株）九電産業，(株）エ邓エムビ 一，（株）第一セメント,また, 1999 年度明治大学卒論生 大浦折宜 君，表幹人君，金丸和樹君，熊野栄一君，斉藤圭君，平野秀明君に 多大な御協力を睗りました。ここに深く謝意を表します。

【参考文献】

[1]吉野利幸，鎌田英治，田畑雅幸，柳敏幸：空隙依存性に基づく コンクリートの強度推定法に関する研究-第 1 報 圧縮強度と空榢棤 造の関係-, 日本建築学会論文報告集, 第 312 号, pp. $9 \sim 16$, 昭和 52 年 2 月

[2]湯浅昇，笠井芳夫他:乾燥条件が微少セメントベーストの水和， 細孔構造及び強度に及ぼす影響，日本建築学会構造系論文集 第 50.5 号, pp.15 21, 1998.3

[3] 小山明男, 料池雅史, 三浦隆広, 椱本浩士 : 高強度軽量コンク リートの細孔構造に関する研究，日本建築学会構造系論文集 第 516 号, pp.7 13, 1999.2

[4] 道正泰弘, 菊池雅史, 増田明，小山明男，三浦隆広：再生細骨 材を用いたコンクリートの構造用コンクリートへの適用一原モル夕 ルの性質が再生細骨材および再生コンクリートの品質に及ぼす影響一, 日本建築学会構造系論文集，第502 号，pp.15〜22，1997.12

(2000年11月10日原稿受理，2001年 4 月 20 日採用決定) 